\title{
LVIS Jr Device for Y-Stent-Assisted Coil Embolization of Wide-Neck Intracranial Aneurysms: A Multicenter Experience
}

\author{
Edgar A. Samaniego ${ }^{a} \quad$ Aldo A. Mendez ${ }^{a}$ Thanh N. Nguyen ${ }^{b}$ \\ Vladimir Kalousek ${ }^{c}$ Waldo R. Guerrero ${ }^{a}$ Sudeepta Dandapat ${ }^{a}$ \\ Guilherme Dabus $^{d}$ Italo Linfante ${ }^{d}$ Ameer E. Hassan $^{e}$ Alexander Drofa ${ }^{f}$ \\ Evgueni Kouznetsov $^{f}$ David Leedahlg ${ }^{\text {David Hasan }}{ }^{\mathrm{h}}$ Alberto Maud ${ }^{\mathrm{i}}$ \\ Santiago Ortega-Gutierrez ${ }^{a}$

\begin{abstract}
aDepartment of Neurology, Neurosurgery and Radiology, University of lowa, lowa, IA, USA; ${ }^{b}$ Department of Neurology, Neurosurgery and Radiology, Boston Medical Center, Boston, MA, USA; 'Department of Radiology, Clinical Hospital Center "Sestre Milosrdnice," Zagreb, USA; ' Valley Baptist Medical Center, Harlingen, TX, USA; ' $D$ Department of Neurosurgery, Sanford Brain \& Spine Center, Fargo, ND, USA; 9 Pharmacy Services, Sanford Medical Center, Fargo, ND, USA; h Department of Neurosurgery, University of lowa, lowa, IA, USA; 'Department of Neurology, Paul L. Foster School of Medicine, Texas Tech University Health Sciences Center, El Paso, TX, USA
\end{abstract} \\ Croatia; ${ }^{\mathrm{d}}$ Miami Cardiac and Vascular Institute and Baptist Neuroscience Center, Miami, FL,
}

\section{Keywords}

Aneurysm $\cdot$ Stenting $\cdot$ Stent-assisted coiling $\cdot$ Y-stent

\begin{abstract}
Background and Purpose: Complex wide-neck intracranial aneurysms are challenging to treat. We report a multicenter experience using the LVIS Jr stent for "Y-stent"-assisted coiling embolization of wide-neck bifurcation aneurysms. Methods: Seven centers provided retrospective data on patients who underwent Y-stenting. Technical complications, immediate posttreatment angiographic results, clinical outcomes, and imaging follow-up were assessed. Results: Thirty patients/aneurysms were treated: 15 basilar tip, 8 middle cerebral artery, 4 anterior communicating artery, 1 pericallosal, and 2 posterior inferior cerebellar artery aneurysms. The mean aneurysm size was $11 \mathrm{~mm}$ and the mean dome-to-neck ratio was $1.3 \mathrm{~mm}$. Twenty-four aneurysms were unruptured and treated electively, and 6 were acutely ruptured. Fifty-eight LVIS Jr stents were successfully deployed without any technical issue. One procedural and transient in-stent thrombosis resolved with the intravenous infusion of a glyco-
\end{abstract}

Edgar A. Samaniego, MD, MS

Clinical Assistant Professor of Neurology, Neurosurgery and Radiology

Office: 2150 RCP, 200 Hawkins Dr.

lowa City, IA 52242 (USA)

E-Mail edgarsama@gmail.com 
protein Ilb/Illa inhibitor. Five periprocedural complications (within 30 days) occurred: 2 periprocedural neurological complications ( 1 small temporal stroke that presented with transient aphasia and 1 posterior cerebral artery infarct) and 3 nonneurological periprocedural complications (2 retroperitoneal hematomas, and 1 patient developed a disseminated intravascular coagulopathy). One permanent complication (3.3\%) directly related to Y-stenting was reported in the patient who suffered the posterior cerebral artery infarct. Immediate complete obliteration (Raymond-Roy Occlusion Classification [RROC] I-II) was achieved in 26 cases (89.6\%). Twenty-four patients had clinical and imaging follow-up (mean 5.2 months). Complete angiographic occlusion (RROC I-II) was observed in 23 patients (96\%). A good functional outcome with a modified Rankin Scale score $\leq 2$ was achieved in 26 cases. Conclusions: In this multicenter case series, Y-stent-assisted coiling of wide-neck aneurysms with the LVIS Jr device was feasible and relatively safe. Follow-up imaging demonstrated very low recanalization rates.

(C) 2018 S. Karger AG, Basel

\section{Introduction}

Several stent configurations have been used for the treatment of wide-neck bifurcation aneurysms. Y-stenting was first described by Chow et al. [1], and since then has been used extensively. The technical success of Y-stenting ranges between 88.9 and $100 \%$, with a procedural complication rate between 0 and 21\% [2]. In vitro studies comparing different stent constructs with the closed-cell Enterprise stent (Codman) demonstrated that the configuration with crossing-Y-stents had the strongest reduction in flow velocity in the sac of the aneurysm due to lower stent porosity and major flow diversion [3]. However, these in vitro models also demonstrated stent narrowing at the point of intersection of the two stents. Clinical data have also shown that Y-stenting has lower rates of recanalization (8.3\%) and retreatment when compared with single-stenting in the treatment of basilar tip aneurysms [4]. However, Y-stenting is not exempt from complications such as stent thrombosis, defective wall apposition of the stent, and incomplete stent opening.

Y-stenting has been described with the closed-cell Enterprise stent and the open-cell Neuroform stent (Stryker). The LVIS Jr (Low-Profile Visualized Intraluminal Support Junior) stent (MicroVention) is a self-expandable stent that consists of a single nitinol wire braid with radiopaque helical strands. It can be deployed through a microcatheter with a 0.0165 -inch inner diameter, facilitating easier access to small and tortuous vessels when compared to other stents delivered through 0.021- and 0.027-inch microcatheters. The LVIS Jr stent has braided and compliant 1.5-mm cells which are moveable and allow recatheterization through the stent cells [5].

We describe a multicenter experience in treating wide-neck bifurcation aneurysms with LVIS Jr stents in a Y-stent configuration.

\section{Methods}

Nonconsecutive patients from seven tertiary centers (University of Iowa, Iowa City, IA, USA; Baptist Neuroscience Center, Miami, FL, USA; Valley Baptist Medical Center, Harlingen, TX, USA; Boston University, Boston, MA, USA; Sestre Milosrdnice Hospital, Zagreb, Croatia; Sanford Brain \& Spine Center, Fargo, ND, USA; and Texas Tech University Health Sciences Center, El Paso, TX, USA) who underwent Y-stenting of wide-neck bifurcation aneurysms using the LVIS Jr device were included in the study. An institutional review board at each institution approved the retrospective analysis of prospectively acquired data. Technical aspects of the procedure, complications, and radiological and clinical outcomes were recorded and analyzed. 


\section{Interventional Neurology}

Fig. 1. Schematic representation of Y-stent-assisted coil embolization of a basilar tip aneurysm. The coiling microcatheter (yellow) is "jailed" in the aneurysm. The first coil is usually partially deployed before stenting. In this way we decrease the risk of aneurysmal perforation, since the coiling microcatheter may move back and forth during stenting. After the first stent has been deployed in the posterior cerebral artery with the most difficult access, we deploy the second stent through the first stent. We then access the aneurysm with a Headway 17 microcatheter (green) through the interstices of the second stent to perform a two-microcatheter coiling. In this way we achieve better packing, since the aneurysm is coiled from two different compartments.

\begin{tabular}{|c|c|}
\hline \multicolumn{2}{|c|}{ Intervent Neurol 2018;7:271-283 } \\
\hline DOI: $10.1159 / 000487545$ & $\begin{array}{l}\text { (c) } 2018 \text { S. Karger AG, Basel } \\
\text { www.karger.com/ine }\end{array}$ \\
\hline
\end{tabular}

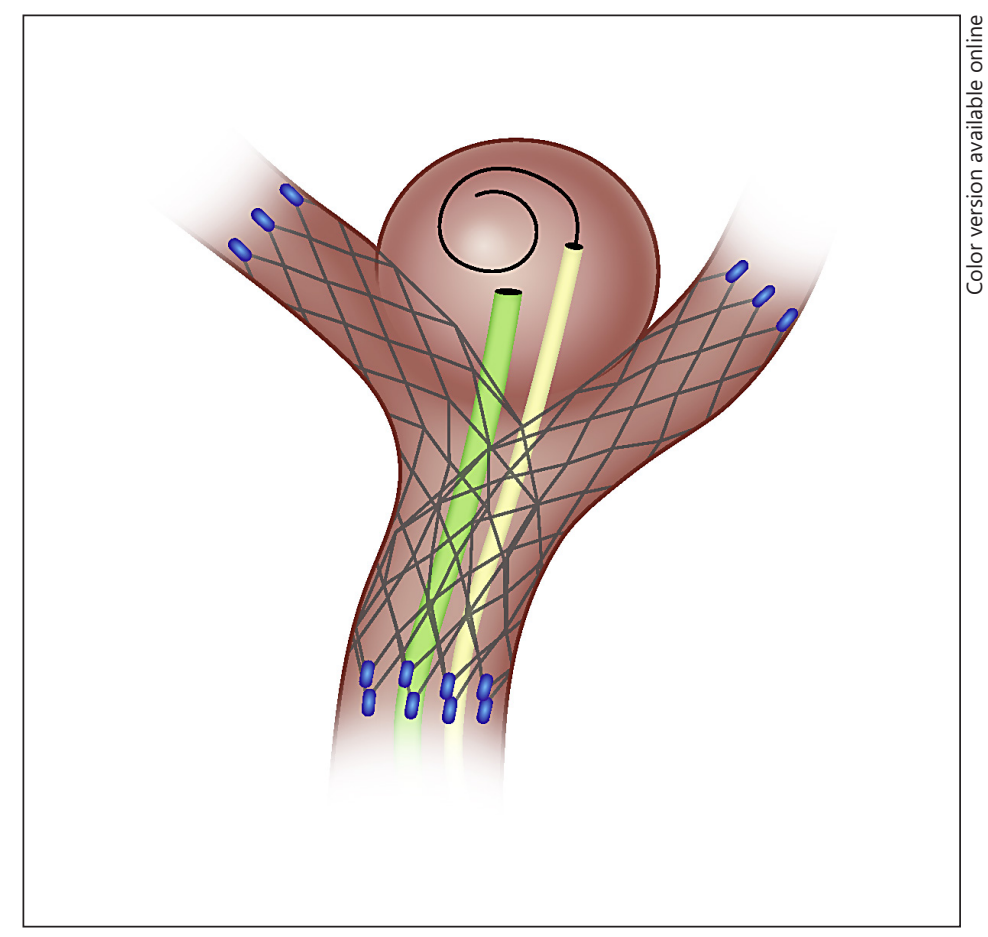

Anticoagulation and Antiplatelet Protocols

All elective cases received dual antiplatelet therapy at least 7 days before the procedure: acetylsalicylic acid (ASA) (81/325 mg/day), clopidogrel $(75 \mathrm{mg} /$ day), or ticagrelor (90 mg b.i.d.). Patients with an acute subarachnoid hemorrhage received a loading dose of $325 \mathrm{mg}$ ASA, $300 \mathrm{mg}$ clopidogrel, or $90 \mathrm{mg}$ ticagrelor the day before the procedure. One patient received cilostazol (100 mg b.i.d.) due to ASA allergy. Four of the seven participating centers monitored and modified the antiplatelet therapy based on individual responses. If responses to ASA and clopidogrel were below the therapeutic range, patients were given an extra dose of ASA or clopidogrel before the procedure. During the procedure, heparin was administered to achieve an activated clotting time $\geq 250 \mathrm{~s}$.

\section{Endovascular Technique}

All interventions were performed under general anesthesia after informed consent had been obtained. In general, an intermediate access catheter was positioned in either the intracranial internal carotid artery or the V3 segment of the vertebral artery. The aneurysmal sac was accessed with a 0.017 -inch microcatheter, and a loop of the first coil was partially deployed in the aneurysm to prevent perforation of the aneurysm while stenting. Subsequently, the side branch with the most challenging access was catheterized with a Headway 17 microcatheter (MicroVention). Then the first stent was slowly deployed while the first microcatheter was jailed. A second LVIS Jr stent was then deployed to achieve a "Y configuration." In this way, the second stent was placed through the first stent. The aneurysm was then coiled through the jailed microcatheter (Fig. 1). In some cases the Headway microcatheter used to deploy the second LVIS Jr stent was used to access the aneurysm and perform dual coiling with two microcatheters of two different aneurysmal compartments. This was intended to achieve a better packing density (Fig. 1).

\section{Clinical and Radiological Follow-Up}

Patients were closely monitored in the intensive care unit after treatment. In general, dual antiplatelets were administered for at least 3 months. Postoperative follow-up with a catheter angiogram or magnetic resonance angiography was typically performed within 6 months after the intervention. Angiographic occlusion of the aneurysm was graded utilizing the Raymond-Roy Occlusion Classification (RROC). Functional outcome was defined utilizing the modified Rankin Scale (mRS). 


\section{Results}

A total of 30 patients were treated, 20 of whom were women (66.6\%). The mean age was 63 years (range 42-78). The following aneurysms were included: basilar tip ( $n=15)$; middle cerebral artery (MCA) $(n=8)$; anterior communicating artery $(n=4)$; pericallosal artery $(n=$ 1 ); and posterior inferior cerebellar artery (PICA) aneurysms $(n=2)$. A PICA aneurysm and the pericallosal artery aneurysm had a fusiform shape, the rest were saccular aneurysms. Twenty-four aneurysms were unruptured and treated electively, and 6 were acutely ruptured. The mean aneurysm size was $11 \mathrm{~mm}$ (range 3-30), with a mean dome-to-neck ratio of $1.3 \mathrm{~mm}$ (range 0.7-2.3). Fifty-eight LVIS Jr stents were successfully deployed. No technical difficulties with stent deployment were reported (Table 1). One procedural and transient in-stent thrombosis (IST) occurred after placement of the first stent in re-treating an anterior communicating artery aneurysm (patient 19). The IST was probably related to tortuosity of the A1/A2 segment and poor stent expansion at this level. The IST resolved after angioplasty of the stent with a Scepter balloon (MicroVention) to achieve better wall apposition and after intravenous administration of a glycoprotein IIb/IIIa inhibitor (GPI).

Patient 11 developed basilar artery thrombosis after placement of a Woven EndoBridge (WEB) device (Sequent Medical) for treatment of a basilar tip aneurysm. In this patient, LVIS Jr Y-stenting through a Scepter balloon was performed as a bailout maneuver to recanalize the basilar artery. Despite the intra-arterial (IA) administration of tissue plasminogen activator and intravenous administration of a GPI, the patient died due to a basilar artery occlusion. Since the initial thrombotic event was not a direct consequence of Y-stenting with an LVIS Jr stent, this event was not accounted a complication in this series. Patient 30 also underwent placement of a WEB device. However, part of the device was protruding into the basilar artery bifurcation. Y-stenting was performed as a bailout maneuver, achieving great intrasaccular positioning of the WEB device.

Five patients (5/29) experienced periprocedural complications: 2 were neurological complications ( 1 transient aphasia due to a temporal lobe stroke and 1 posterior cerebral artery infarct) and 3 were nonneurological complications ( 2 retroperitoneal hematomas and 1 disseminated intravascular coagulation). The patient with the transient aphasia completely recovered before discharge (patient 7). Brain magnetic resonance imaging demonstrated a small stroke in the temporal lobe. Patient 12 developed a posterior cerebral artery occlusion $1 \mathrm{~h}$ after extubation. Despite IA infusion of GPIs, the posterior cerebral artery did not recanalize. An attempt to place a balloon into the stent for angioplasty was unsuccessful, and the patient suffered a right midbrain and posterior cerebral artery territory stroke. This patient had an mRS score of 4 on follow-up.

The 2 patients with retroperitoneal hematomas (patients 10 and 17) had symptomatic hypotension. One of these patients was a hyperresponder to clopidogrel with a platelet reactivity of 7 units (reference 194-418). Both patients were discharged home with a normal neurological examination. A patient with a ruptured PICA aneurysm developed disseminated intravascular coagulation during the procedure and required multiple blood and platelet transfusions (patient 22). Despite maximal medical therapy, the patient developed systemic complications with lung hemorrhage and the family decided to withdraw care. Patient 23 presented with a ruptured basilar tip aneurysm and a Hunt and Hess grade of 4 . The patient had an eventful hospitalization with vasospasm and multiple medical complications. Although the endovascular treatment was successful, the patient did notshowneurologicalimprovement and the family withdrew care. Asymptomatic intimal hyperplasia in an LVIS Jr stent placed in an A2 segment was visualized on the 6-month follow-up diagnostic angiogram of patient 4.

Patient 15 underwent treatment of an MCA bifurcation aneurysm with a Barrel device (Reverse Medical). Due to incomplete neck coverage, it was decided to perform Y-stenting 
Table 1. Patient characteristics

\begin{tabular}{|c|c|c|c|c|c|c|c|c|c|c|c|c|c|c|}
\hline $\begin{array}{l}\mathrm{Pa}- \\
\text { tient }\end{array}$ & $\begin{array}{l}\text { Age, } \\
\text { years/ } \\
\text { gender }\end{array}$ & $\begin{array}{l}\text { Lo- } \\
\text { cation }\end{array}$ & $\begin{array}{l}\mathrm{AS}, \\
\mathrm{mm}\end{array}$ & $\begin{array}{l}\mathrm{NS}, \\
\mathrm{mm}\end{array}$ & $\begin{array}{l}\mathrm{D} / \mathrm{N} \\
\mathrm{mm}\end{array}$ & $P$ & $\begin{array}{l}\text { Stent \#1: } \\
\text { size, } \mathrm{mm}\end{array}$ & $\begin{array}{l}\text { Stent \#2: } \\
\text { size, } \mathrm{mm}\end{array}$ & $\begin{array}{l}\text { Im- } \\
\text { mediate } \\
\text { RROC }\end{array}$ & $\begin{array}{l}\text { Procedural } \\
\text { compli- } \\
\text { cations }\end{array}$ & $\begin{array}{l}\text { 30-day } \\
\text { compli- } \\
\text { cations }\end{array}$ & $\begin{array}{l}\mathrm{F} / \mathrm{u} \text {, } \\
\text { months/ } \\
\text { modality }\end{array}$ & $\begin{array}{l}\text { F/u } \\
\text { RROC }\end{array}$ & $\begin{array}{l}\text { Out-come, } \\
\text { mRS score }\end{array}$ \\
\hline 1 & $57 / \mathrm{F}$ & MCA & $6 \times 3$ & 3 & 1 & $\mathrm{R}$ & $\begin{array}{l}\text { LVIS Jr } \\
2.5 \times 17\end{array}$ & $\begin{array}{l}\text { LVIS Jr } \\
3.5 \times 23\end{array}$ & I & $\mathrm{N}$ & $\mathrm{N}$ & 6/DSA & I & 0 \\
\hline 2 & $72 / \mathrm{M}$ & MCA & $5 \times 5$ & 4 & 1.2 & $\mathrm{R}$ & $\begin{array}{l}\text { LVIS Jr } \\
2.5 \times 17\end{array}$ & $\begin{array}{l}\text { LVIS Jr } \\
2.5 \times 23\end{array}$ & I & $\mathrm{N}$ & $\mathrm{N}$ & 6/DSA & I & 2 \\
\hline 3 & $42 / \mathrm{M}$ & BT & $10 \times 13$ & 11 & 1.2 & UR & $\begin{array}{l}\text { LVIS Jr } \\
2.5 \times 23\end{array}$ & $\begin{array}{l}\text { LVIS Jr } \\
2.5 \times 17\end{array}$ & I & $\mathrm{N}$ & $\mathrm{N}$ & 6/DSA & I & 0 \\
\hline 4 & $76 / \mathrm{M}$ & ACOM & $5 \times 4$ & 4 & 1 & UR & $\begin{array}{l}\text { LVIS Jr } \\
2.5 \times 23\end{array}$ & $\begin{array}{l}\text { LVIS Jr } \\
2.5 \times 23\end{array}$ & I & $\mathrm{N}$ & $\mathrm{N}$ & 5/MRA & I & 1 \\
\hline 5 & $59 / \mathrm{F}$ & BT & $8 \times 8$ & 7 & 1.1 & UR & $\begin{array}{l}\text { LVIS Jr } \\
3.5 \times 28\end{array}$ & $\begin{array}{l}\text { LVIS Jr } \\
2.5 \times 23\end{array}$ & IIIa & $\mathrm{N}$ & $\mathrm{N}$ & 6/DSA & II & 1 \\
\hline 6 & $69 / \mathrm{F}$ & BT & $6 \times 7$ & 5 & 1.4 & UR & $\begin{array}{l}\text { LVIS Jr } \\
3.5 \times 23\end{array}$ & $\begin{array}{l}\text { LVIS Jr } \\
2.5 \times 23\end{array}$ & IIIa & $\mathrm{N}$ & $\mathrm{N}$ & 6/DSA & IIIa & 0 \\
\hline 7 & $69 / \mathrm{F}$ & MCA & $3 \times 3$ & 4 & 0.7 & UR & $\begin{array}{l}\text { LVIS Jr } \\
2.5 \times 23\end{array}$ & $\begin{array}{l}\text { Neuroform } \\
2.5 \times 15\end{array}$ & I & $\mathrm{N}$ & S & 6/DSA & I & 0 \\
\hline 8 & $61 / \mathrm{F}$ & BT & $8 \times 9$ & 4 & 2.2 & UR & $\begin{array}{l}\text { LVIS Jr } \\
2.5 \times 23\end{array}$ & $\begin{array}{l}\text { LVIS Jr } \\
2.5 \times 17\end{array}$ & I & $\mathrm{N}$ & $\mathrm{N}$ & $5 / \mathrm{DSA}$ & I & 0 \\
\hline 9 & $78 / \mathrm{F}$ & MCA & $7 \times 7$ & 5 & 1.4 & UR & $\begin{array}{l}\text { LVIS Jr } \\
2.5 \times 23\end{array}$ & $\begin{array}{l}\text { LVIS Jr } \\
2.5 \times 17\end{array}$ & IIIa & $\mathrm{N}$ & $\mathrm{N}$ & 4/DSA & I & 0 \\
\hline 10 & $54 / \mathrm{F}$ & BT & $16 \times 11$ & 9 & 1.2 & UR & $\begin{array}{l}\text { LVIS Jr } \\
3.5 \times 28\end{array}$ & $\begin{array}{l}\text { LVIS Jr } \\
3.5 \times 28\end{array}$ & II & $\mathrm{N}$ & $\mathrm{RH}$ & 7/DSA & I & 0 \\
\hline 11 & $62 / \mathrm{F}$ & BT & $7 \times 5$ & 5 & 1 & UR & $\begin{array}{l}\text { LVIS Jr } \\
3.5 \times 23\end{array}$ & $\begin{array}{l}\text { LVIS Jr } \\
3.5 \times 18\end{array}$ & - & $\mathrm{N}$ & Death & - & - & 6 \\
\hline 12 & $47 / F$ & BT & $15 \times 15$ & 11 & 1.3 & UR & $\begin{array}{l}\text { LVIS Jr } \\
3.5 \times 28\end{array}$ & $\begin{array}{l}\text { LVIS Jr } \\
3.5 \times 23\end{array}$ & II & $\mathrm{N}$ & S & $11 / \mathrm{DSA}$ & II & 4 \\
\hline 13 & $78 / \mathrm{F}$ & ACOM & $4 \times 6$ & 4 & 1.5 & UR & $\begin{array}{l}\text { LVIS Jr } \\
2.5 \times 23\end{array}$ & $\begin{array}{l}\text { LVIS Jr } \\
2.5 \times 17\end{array}$ & II & $\mathrm{N}$ & $\mathrm{N}$ & 6/DSA & I & 0 \\
\hline 14 & $71 / \mathrm{F}$ & BT & $9 \times 7$ & 8 & 0.8 & UR & $\begin{array}{l}\text { LVIS Jr } \\
3.5 \times 23\end{array}$ & $\begin{array}{l}\text { LVIS Jr } \\
3.5 \times 18\end{array}$ & I & $\mathrm{N}$ & $\mathrm{N}$ & 6/DSA & I & 0 \\
\hline 15 & $62 / \mathrm{F}$ & MCA & $4 \times 4$ & 4 & 1 & $\mathrm{R}$ & $\begin{array}{l}\text { LVIS Jr } \\
2.5 \times 23\end{array}$ & $\begin{array}{l}\text { Barrel } \\
3.5 \times 5 \times 20\end{array}$ & I & $\mathrm{N}$ & $\mathrm{N}$ & 6/DSA & I & 0 \\
\hline 16 & $69 / \mathrm{M}$ & BT & $5 \times 3$ & 3 & 1 & UR & $\begin{array}{l}\text { LVIS Jr } \\
2.5 \times 23\end{array}$ & $\begin{array}{l}\text { LVIS Jr } \\
2.5 \times 17\end{array}$ & II & $\mathrm{N}$ & $\mathrm{N}$ & 3/MRA & II & 0 \\
\hline 17 & $63 / \mathrm{M}$ & MCA & $5 \times 4$ & 3 & 1.3 & UR & $\begin{array}{l}\text { LVIS Jr } \\
3.5 \times 23\end{array}$ & $\begin{array}{l}\text { LVIS Jr } \\
2.5 \times 17\end{array}$ & II & $\mathrm{N}$ & $\mathrm{RH}$ & 3/MRA & I & 0 \\
\hline 18 & $65 / F$ & BT & $8 \times 7$ & 4 & 1.7 & UR & $\begin{array}{l}\text { LVIS Jr } \\
2.5 \times 23\end{array}$ & $\begin{array}{l}\text { LVIS Jr } \\
2.5 \times 17\end{array}$ & II & $\mathrm{N}$ & $\mathrm{N}$ & 3/MRA & II & 0 \\
\hline 19 & $55 / \mathrm{M}$ & ACOM & $5 \times 4$ & 4 & 1 & $\mathrm{R}$ & $\begin{array}{l}\text { LVIS Jr } \\
2.5 \times 23\end{array}$ & $\begin{array}{l}\text { LVIS Jr } \\
3.5 \times 18\end{array}$ & I & IST & $\mathrm{N}$ & 3/MRA & I & 0 \\
\hline 20 & $68 / \mathrm{F}$ & BT & $30 \times 30$ & 13 & 2.3 & UR & $\begin{array}{l}\text { LVIS Jr } \\
3.5 \times 23\end{array}$ & $\begin{array}{l}\text { LVIS Jr } \\
3.5 \times 23\end{array}$ & I & $\mathrm{N}$ & $\mathrm{N}$ & $3 / \mathrm{DSA}$ & II & 2 \\
\hline 21 & $69 / \mathrm{M}$ & ACOM & $22 \times 22$ & 14 & 1.6 & UR & $\begin{array}{l}\text { LVIS Jr } \\
3.5 \times 23\end{array}$ & $\begin{array}{l}\text { LVIS Jr } \\
3.5 \times 23\end{array}$ & I & $\mathrm{N}$ & $\mathrm{N}$ & 12/DSA & I & 0 \\
\hline 22 & $76 / \mathrm{F}$ & PICA & $3 \times 3$ & 3.5 & 0.9 & $\mathrm{R}$ & $\begin{array}{l}\text { LVIS Jr } \\
3.5 \times 23\end{array}$ & $\begin{array}{l}\text { LVIS Jr } \\
4.5 \times 23\end{array}$ & I & $\mathrm{N}$ & DIC & - & - & 6 \\
\hline 23 & $58 / \mathrm{F}$ & BT & $14 \times 14$ & 12 & 1.2 & $\mathrm{R}$ & $\begin{array}{l}\text { LVIS Jr } \\
3.5 \times 23\end{array}$ & $\begin{array}{l}\text { LVIS Jr } \\
3.5 \times 23\end{array}$ & I & $\mathrm{N}$ & $\mathrm{N}$ & $0.25 / \mathrm{DSA}$ & I & 6 \\
\hline 24 & $66 / F$ & BT & $9 \times 9$ & 8 & 1.1 & $\mathrm{R}$ & $\begin{array}{l}\text { LVIS Jr } \\
3.5 \times 23\end{array}$ & $\begin{array}{l}\text { LVIS Jr } \\
3.5 \times 23\end{array}$ & I & $\mathrm{N}$ & $\mathrm{N}$ & 12/DSA & I & 0 \\
\hline 25 & $61 / \mathrm{M}$ & PICA & $4 \times 4$ & 4 & 1 & UR & $\begin{array}{l}\text { LVIS Jr } \\
3.5 \times 23\end{array}$ & $\begin{array}{l}\text { LVIS Jr } \\
4.5 \times 23\end{array}$ & I & $\mathrm{N}$ & $\mathrm{N}$ & 6/DSA & I & 0 \\
\hline 26 & $66 / F$ & BT & $11 \times 11$ & 7 & 1.6 & UR & $\begin{array}{l}\text { LVIS Jr } \\
3.5 \times 23\end{array}$ & $\begin{array}{l}\text { LVIS Jr } \\
3.5 \times 23\end{array}$ & I & $\mathrm{N}$ & $\mathrm{N}$ & 6/DSA & I & 0 \\
\hline 27 & $67 / \mathrm{M}$ & MCA & $9 \times 9$ & 4 & 2.2 & UR & $\begin{array}{l}\text { LVIS Jr } \\
2.5 \times 17\end{array}$ & $\begin{array}{l}\text { LVIS Jr } \\
2.5 \times 17\end{array}$ & I & $\mathrm{N}$ & $\mathrm{N}$ & 6/MRA & I & 0 \\
\hline 28 & $58 / \mathrm{M}$ & MCA & $5 \times 4$ & 3 & 1.6 & UR & $\begin{array}{l}\text { LVIS Jr } \\
3.5 \times 18\end{array}$ & $\begin{array}{l}\text { LVIS Jr } \\
2.5 \times 13\end{array}$ & I & $\mathrm{N}$ & $\mathrm{N}$ & Pending & Pending & 0 \\
\hline 29 & $61 / \mathrm{F}$ & $\begin{array}{l}\text { Peri- } \\
\text { callosal }\end{array}$ & $6 \times 4$ & 4 & 1.5 & UR & $\begin{array}{l}\text { LVIS Jr } \\
2.5 \times 23\end{array}$ & $\begin{array}{l}\text { LVIS Jr } \\
2.5 \times 23\end{array}$ & I & $\mathrm{N}$ & $\mathrm{N}$ & Pending & Pending & 0 \\
\hline 30 & $60 / \mathrm{F}$ & BT & $9 \times 8$ & 6 & 1.5 & UR & $\begin{array}{l}\text { LVIS Jr } \\
2.5 \times 23\end{array}$ & $\begin{array}{l}\text { LVIS Jr } \\
3.5 \times 23\end{array}$ & I & $\mathrm{N}$ & $\mathrm{N}$ & Pending & Pending & 0 \\
\hline
\end{tabular}

MCA, middle cerebral artery; BT, basilar tip; ACOM, anterior communicating artery; PICA, posterior inferior cerebellar artery; AS, aneurysm size; NS, neck size; D/N, dome-to-neck ratio; P, presentation; R, ruptured; UR, unruptured; RROC, Raymond-Roy Occlusion Classification; N, none; IST, in-stent thrombosis; S, stroke; $\mathrm{RH}$, retroperitoneal hematoma; DIC, disseminated intravascular coagulation; F/u, follow-up; DSA, digital subtraction angiography; mRS, modified Rankin Scale. 
Samaniego et al.: Y-Stenting of Complex Wide-Neck Aneurysms with the LVIS Jr Device
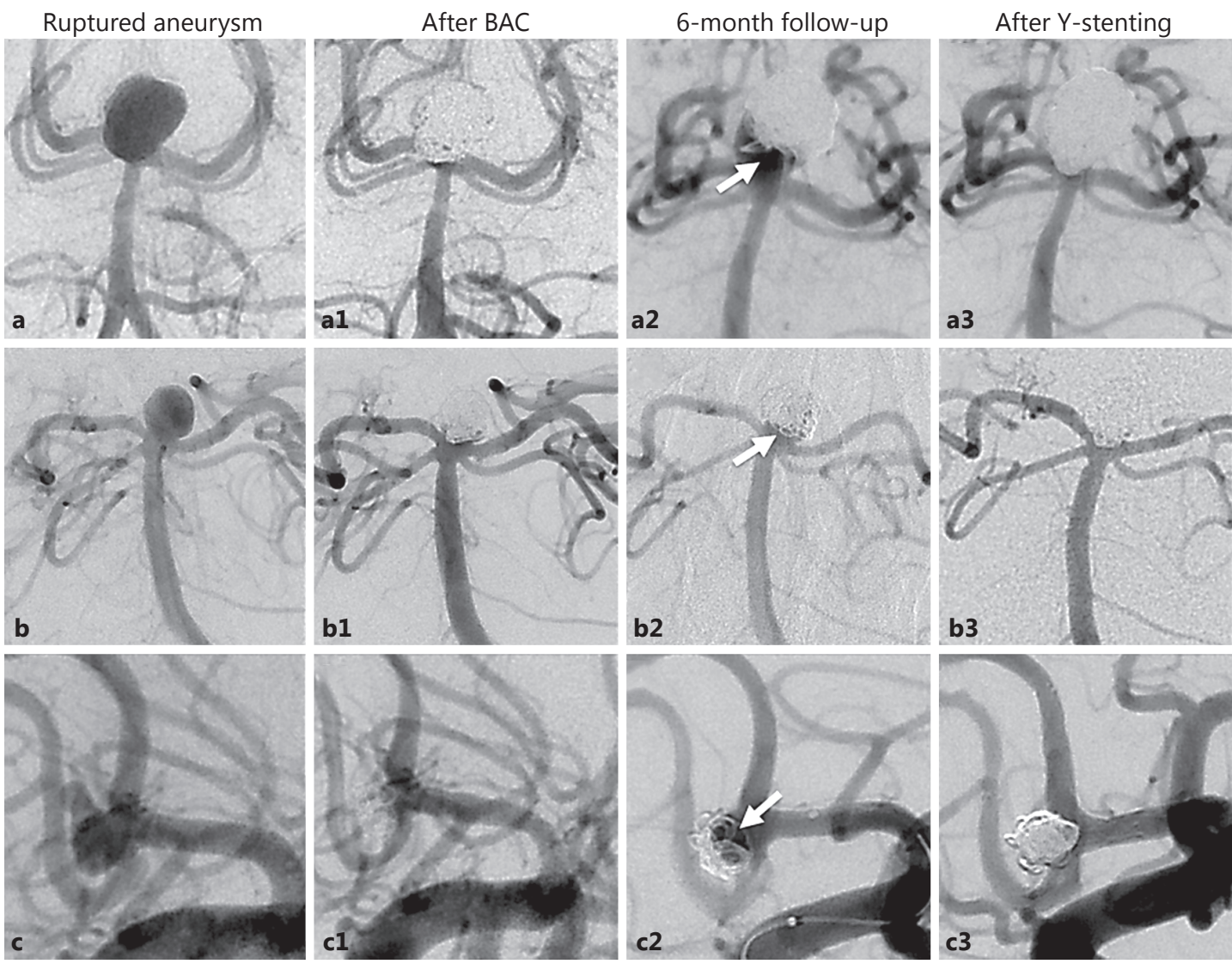

Fig. 2. Three patients with acutely ruptured basilar artery $(\mathbf{a}, \mathbf{b})$ and anterior communicating artery (c) aneurysms underwent balloon-assisted coiling (BAC). The posttreatment angiograms demonstrated a minimal residual neck (a1-c1). The 6-month follow-up diagnostic angiograms demonstrated aneurysm recurrence and coil compaction (a2-c2 , white arrows). The patients underwent Y-stenting (a3-c3) with no evidence of recurrence on follow-up imaging.

Fig. 3. a Unruptured left middle cerebral artery aneurysm treated with two LVIS Jr stents $(2.5 \times 13$ $\mathrm{mm}$ in the superior M2 division and $3.5 \times 18 \mathrm{~mm}$ in the inferior M2 division). b Notice the change of angulation and superior division side branch geometry after placement of the LVIS Jr devices.
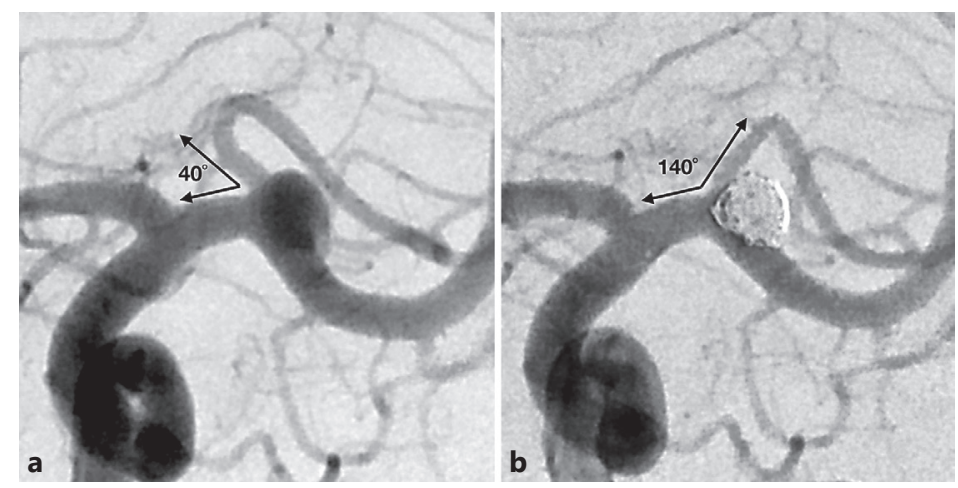

with an LVIS Jr stent. Patients 3,16, and 19 presented with ruptured aneurysms and were treated with balloon-assisted coiling, achieving an RROC of II (Fig. 2). Recanalization was documented on the follow-up diagnostic angiography, and Y-stenting was performed as a definite treatment. Patient 7 presented with recanalization of a previously treated left MCA aneurysm with stent-assisted coiling (Neuroform). This patient underwent successful 
retreatment with an LVIS Jr stent in a Y-stent configuration with the previously deployed stent.

Immediate complete obliteration (RROC I-II) was achieved in 26 cases (89.6\%), and residual aneurysm (RROC IIIa) in 3 cases (11\%). Twenty-four patients had clinical and imaging follow-up (a mean of 5.2 months). Angiographic occlusion of the aneurysm (RROC I-II) on follow-up was observed in 23 patients (96\%), and partial aneurysm recanalization (RROC IIIa) in 1 patient (4\%). A good functional outcome (mRS score $\leq 2$ ) was observed in 26 cases. No patients underwent additional endovascular treatments after Y-stenting. Only 1 patient (3.3\%) had permanent neurologic deficits related to Y-stenting on follow-up.

\section{Discussion}

Y-stent-assisted coiling has been described as a feasible alternative to microsurgical clipping for a subset of challenging bifurcation aneurysms. This multicenter case series demonstrates that Y-stenting with the braided low-profile stent LVIS Jr is technically feasible. We did not experience any complications accessing bifurcation branches or during stent deployment. Fifty-seven of the 58 deployed stents were well apposed to the parent artery and protected the aneurysm's neck for coiling. In 1 case the stent was not well apposed to a tortuous A1/A2 segment and required angioplasty. In 2 cases the Y-stent construct was formed with an LVIS Jr stent and a different device: a Neuroform stent and a Barrel device.

Y-stenting offers multiple advantages in aneurysm remodeling: support to prevent coil mass herniation, blood flow diversion, a scaffold for neo-endothelialization, modification of the parent vessel-aneurysm geometry, and remodeling of the affected branches (Fig. 3) [6, 7]. Moreover, the flow diversion effect of Y-stenting or even of LVIS Jr alone could result in successful and stable aneurysm occlusion without aneurysm coiling [8-10]. This has been reported for small bifurcation aneurysms in which the angioarchitecture of the parent arteries and the aneurysm is modified, favoring aneurysm occlusion. Computational fluid models have shown that Y-stent configurations redirect the flow away from the center of the aneurysmal neck, resulting in the greatest cross-neck flow reduction of wide-neck basilar aneurysms, more than with single stenting or T-stenting [11]. Y-stenting also decreases the shear stress inside the aneurysm sac by $>40 \%$ [12].

The LVIS Jr stent can be safely deployed in parent vessels $<2 \mathrm{~mm}$ through a 0.0165 -inch microcatheter [10]. This is the smallest available stent delivery system. Selective catheterization of aneurysmal side branches is easier with smaller microcatheters. The LEO Baby (Balt), Acclino (Acandis), and Neuroform Atlas (Stryker) stents can also be delivered through a 0.0165-inch microcatheter. The LEO Baby stent is a braided stent like the LVIS Jr, whereas the Acclino is a laser-cut closed-cell stent and the Neuroform Atlas is a laser-cut hybrid-cell stent (Table 2). Machi et al. [13] reported a 17\% complication rate (3 IST) with the LEO Baby stent. Akmangit et al. [14] reported the largest series of Y-stenting with the LEO Baby stent (4 patients). The authors underlined the advantages of these braided stents over other lasercut open- and closed-cell stents (Enterprise, Neuroform, and Solitaire [Medtronic]), mainly better wall apposition and scaffolding. Tureli et al. [15] described 11 Y-stenting procedures with the Acclino stent with an $18 \%$ complication rate. The authors emphasize the closed-cell design of the Acclino stent with an electropolished surface, which theoretically decreases thrombogenicity. However, this design decreases stent conformability and enhances angular remodeling [15]. Similarly, Kabbasch et al. [16] described 3 cases of Y-stenting with the Acclino stent, with a 33\% complication rate: 1 IST, which resolved with IA GPIs. Brassel et al. [17] reported their experience of kissing-Y-stenting with the Acclino stent, with a $14 \%$ complication rate (1/7). Ciccio et al. [18] reported their experience with the Neuroform Atlas stent 
Table 2. Characteristics of the low-profile stents

\begin{tabular}{llllll}
\hline Stent & Struts & $\begin{array}{l}\text { Cell size, } \\
\mathrm{mm}\end{array}$ & Type & $\begin{array}{l}\text { Resheathable } \\
\text { length }\end{array}$ & Visibility \\
\hline Acclino & Fixed & 1.8 & $\begin{array}{l}\text { Laser cut; } \\
\text { closed cell }\end{array}$ & $90 \%$ & $\begin{array}{l}\text { Proximal - } \\
\text { distal ends }\end{array}$ \\
\hline LVIS Jr & Mobile & 1.5 & $\begin{array}{l}\text { Braided; } \\
\text { closed cell }\end{array}$ & $80 \%$ & Entire length \\
\hline LEO Baby & Mobile & 0.9 & $\begin{array}{l}\text { Braided; } \\
\text { hybrid cell }\end{array}$ & $95 \%$ & Entire length \\
\hline $\begin{array}{l}\text { Neuroform } \\
\text { Atlas }\end{array}$ & Hybrid & - & $\begin{array}{l}\text { Laser cut; } \\
\text { hybrid cell }\end{array}$ & $0 \%$ & $\begin{array}{l}\text { Proximal - } \\
\text { distal ends }\end{array}$ \\
\hline
\end{tabular}

Fig. 4. a In vitro configuration of a Y-stent construct with two LVIS Jr stents $(3.5 \times 23$ and $3.5 \times 28$ $\mathrm{mm}$ ) in a silicone model (Courtesy of MicroVention). b DynaCT (Siemens) image of a basilar tip aneurysm treated with Y-stenting-assisted coiling (LVIS Jr $2.5 \times$ 23 and $2.5 \times 17 \mathrm{~mm}$ ). Note that the stents are completely expanded at the point of intersection of the two stents in the silicone model (a, black arrow) and the DynaCT image (b, white arrow).
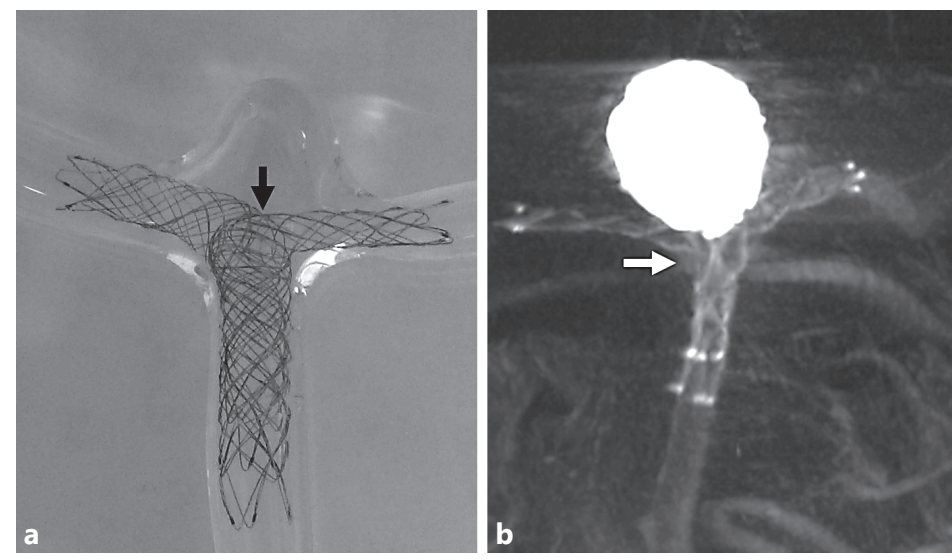

in treating 36 aneurysms, 2 by Y-stenting. The complication rate was 5.5\%, with 1 aneurysm perforation and 1 parent vessel perforation while attempting to implant the stent.

The LVIS Jr device has a small cell size of $1.5 \mathrm{~mm}$, which may improve flow diversion and protect against coil protrusion [19]. The cells are also movable since they are braided, allowing catheterization of the aneurysm through the interstices and better configuration of the Y-stent construct (Fig. 4). This advantage has also been described for the other low-profile braided stent, the LEO Baby [14]. Moreover, the entire LVIS Jr stent is visible during fluoroscopy due to three interwoven radiopaque helical strands. Positioning and expansion of the device can be easily verified after deployment.

Previous series have reported low rates of deployment failure and ease of navigability with the LVIS Jr device [20-23]. Conrad et al. [24] described the first 2 cases of Y-stenting with the LVIS Jr stent for the treatment of basilar tip aneurysms. In their case series of 85 wideneck aneurysms treated with LVIS Jr stents, Grossberg et al. [21] described only 1 deployment failure (1\%). Some studies have reported stent migration with braided stents [14, 25]. We did not encounter any technical issues with the deployment or stability of the device in the 58 cases of this series. Later versions of the LVIS Jr stent have an increased radial force, which may explain why we did not experience any stent migration [23]. As opposed to the Neuroform Atlas stent, the LVIS Jr stent can be resheathed (up to 80\%) to achieve a better position. Once completely deployed, we usually access the distal end of the stent with the delivery micro- 


\section{Interventional Neurology}

Intervent Neurol 2018;7:271-283

S. Karger AG, Base www.karger.com/ine

Samaniego et al.: Y-Stenting of Complex Wide-Neck Aneurysms with the LVIS Jr Device

Table 3. Published series ( $\geq 2$ cases) describing Y-stent-assisted coil embolization

\begin{tabular}{|c|c|c|c|c|c|c|}
\hline First author [Ref.] & $\begin{array}{l}\text { Patients/ } \\
\text { aneurysms, } n\end{array}$ & Location, $n$ & Stents & $\begin{array}{l}\text { Technical } \\
\text { success rate, } \%\end{array}$ & $\begin{array}{l}\text { Immediate } \\
\text { RROC, } \%\end{array}$ & Complications, $n$ \\
\hline Akgul [32] & 9 & $\begin{array}{l}\text { ACOM: } 3 \\
\text { MCA: } 2 \\
\text { BT: } 4\end{array}$ & $\begin{array}{l}\text { Enterprise and } \\
\text { Neuroform }\end{array}$ & 88.9 & - & $\begin{array}{l}\text { Stent protrusion: } 1 \\
\text { IST: } 1\end{array}$ \\
\hline Castano [33] & 45 & $\begin{array}{l}\text { ACOM: } 17 \\
\text { MCA: } 20 \\
\text { BT: } 4 \\
\text { ICA: } 3 \\
\text { PCOM: } 1\end{array}$ & Neuroform & 100 & - & IST: 1 \\
\hline Chalouhi [4] & 16 & BT & $\begin{array}{l}\text { Enterprise and } \\
\text { Neuroform }\end{array}$ & - & I-II: 81 & IST: 1 \\
\hline Darkhabani [34] & 4 & Pericallosal & Neuroform & 100 & - & None \\
\hline Fargen [26] & 45 & $\begin{array}{l}\text { ACOM: } 3 \\
\text { MCA: } 2 \\
\text { BT: } 39 \\
\text { Pericallosal: } 1\end{array}$ & $\begin{array}{l}\text { Enterprise and } \\
\text { Neuroform }\end{array}$ & 100 & I-II: 84 & $\begin{array}{l}\text { SAH: 2; stent herniation into aneurysm: } 1 \text {; } \\
\text { stent migration: } 1 \text {; event not specified: } 1 \text {; } \\
\text { cranial nerve palsy: } 3 \text {; TIA: } 1 \text {; RH: } 1\end{array}$ \\
\hline Ko [35] & 20 & $\begin{array}{l}\text { ACOM: } 8 \\
\text { MCA: } 1 \\
\text { BT: } 9 \\
\text { Pericallosal: } 2\end{array}$ & Neuroform & 100 & $\begin{array}{l}\text { I-II: } 95 \\
\text { III: } 5\end{array}$ & $\begin{array}{l}\text { IST: 6; SAH: 2; } \\
\text { VA dissection: } 1 \text {; } \\
\text { coil migration: } 1\end{array}$ \\
\hline Limbucci [27] & 48 & $\begin{array}{l}\text { ACOM: } 14 \\
\text { MCA: } 20 \\
\text { BT: } 11 \\
\text { ICA: } 2 \\
\text { VB junction: } 1\end{array}$ & Enterprise & 92.3 & $\begin{array}{l}\text { I-II: } 94 \\
\text { III: } 6\end{array}$ & SAH: 2 \\
\hline Lozen [36] & 6 & $\begin{array}{l}\text { MCA: } 1 \\
\text { BT: } 5\end{array}$ & Neuroform & 100 & - & SAH: 1 ; coil failure: 1 \\
\hline Martínez-Galdámez [28] & 6 & $\begin{array}{l}\text { ACOM: } 2 \\
\text { MCA: } 3 \\
\text { Pericallosal: } 1\end{array}$ & Solitaire AB & 100 & I-II: 100 & None \\
\hline Muda [37] & 2 & $\begin{array}{l}\text { MCA: } 1 \\
\text { BT: } 1\end{array}$ & Solitaire $\mathrm{AB}$ and LEO & 100 & - & None \\
\hline Perez-Arjona [38] & 3 & BT & Neuroform & 100 & - & None \\
\hline Spiotta [2] & 19 & $\begin{array}{l}\text { ACOM: } 1 \\
\text { BT: } 18\end{array}$ & Neuroform & 100 & $\begin{array}{l}\text { I-II: } 53 \\
\text { III: } 47\end{array}$ & $\begin{array}{l}\text { SAH: } 1 \text {; stent migration: } 1 \text {; VA dissection: } \\
1 \text {; stroke: } 5\end{array}$ \\
\hline Thorell [39] & 7 & BT & Neuroform & 85.7 & I-II: 100 & TIA: 2 \\
\hline Yavuz [30] & 183 & $\begin{array}{l}\text { ACOM: } 34 \\
\text { MCA: } 113 \\
\text { ICA: } 15 \\
\text { BT: } 21 \\
\end{array}$ & $\begin{array}{l}\text { Enterprise, } \\
\text { Neuroform, and } \\
\text { Solitaire }\end{array}$ & - & $\begin{array}{l}\text { I-II: } 58 \\
\text { III: } 42\end{array}$ & SAH: 4; IST: 1; stroke: 4 \\
\hline Zhao [31] & 9 & $\begin{array}{l}\text { ACOM: } 2 \\
\text { MCA: } 3 \\
\text { BT: } 3 \\
\text { PCOM: } 1\end{array}$ & $\begin{array}{l}\text { Enterprise and } \\
\text { Neuroform }\end{array}$ & 100 & I-II: 100 & None \\
\hline \multicolumn{7}{|l|}{ Low-profile stents } \\
\hline Möhlenbruch [25] & 8 & $\begin{array}{l}\text { ACOM: } 1 \\
\text { MCA: } 3 \\
\text { BT: } 4\end{array}$ & LVIS Jr & 100 & I-II: 100 & IST: 2 \\
\hline Conrad [24] & 2 & BT: 2 & LVIS Jr & 100 & I-II: 100 & None \\
\hline Behme [5] & 11 & $\begin{array}{l}\text { AC } \\
\mathrm{PC}\end{array}$ & $\begin{array}{l}\text { LVIS Jr, LVIS, } \\
\text { Enterprise, and } \\
\text { Neuroform }\end{array}$ & 100 & I-II: 100 & Vasospasm: 1; IST: 4 \\
\hline Kabbasch [16] & 3 & $\begin{array}{l}\text { ACOM: } 1 \\
\text { MCA: } 1 \\
\text { BT: } 1\end{array}$ & Acclino & 100 & I: 100 & IST: 1 \\
\hline Akmangit [14] & 5 & $\begin{array}{l}\text { ACOM: } 2 \\
\text { MCA: } 2 \\
\text { BT: } 1\end{array}$ & $\begin{array}{l}\text { LEO Baby and } \\
\text { Enterprise }\end{array}$ & 83 & I-II: 100 & SAH: 1 ; stent migration: 1 \\
\hline Tureli [15] & 11 & - & Acclino & 84.6 & I: 100 & SAH: 1 ; IST: 1 \\
\hline Current study & 30 & $\begin{array}{l}\text { ACOM: } 4 \\
\text { MCA: } 8 \\
\text { BT: } 15 \\
\text { PICA: } 2 \\
\text { Pericallosal: } 1\end{array}$ & $\begin{array}{l}\text { LVIS Jr, Barrel, and } \\
\text { Neuroform }\end{array}$ & 100 & $\begin{array}{l}\text { I-II: } 89 \\
\text { III: } 11\end{array}$ & IST: 1 ; stroke: 2 ; RH: 2; DIC: 1 \\
\hline
\end{tabular}

RROC, Raymond-Roy Occlusion Classification; ACOM, anterior communicating artery; MCA, middle cerebral artery; BT, basilar tip; ICA, internal carotid artery; PCOM, posterior communicating artery; VB, vertebrobasilar; AC, anterior circulation; PC, posterior circulation; IST, in-stent thrombosis; SAH, subarachnoid hemorrhage; TIA, transient ischemic attack; RH, retroperitoneal hematoma; DIC, disseminated intravascular coagulation. 
catheter to enhance stent expansion and wall apposition. Poncyljusz et al. [23] described their experience with the LVIS and LVIS Jr stents in treating 78 wide-neck aneurysms. Bioengineering changes achieved with later versions of the LVIS Jr stent have improved the radial force and wall apposition of the device, which may translate into a better success rate during stent delivery. In our series, we only encountered 1 asymptomatic intimal hyperplasia in a stent placed in an A2 segment. We did not encounter any symptomatic stent stenosis, kinking, or stent migration on follow-up.

The reported rates of immediate angiographic occlusion (RROC I or II) with Y-stentassisted coiling range from 52 to $100 \%$ [26-31]. In our series, immediate complete obliteration (RROC I-II) was achieved in $89.6 \%$ of the cases, similar to what has been described by Behme et al. [5]. Table 3 summarizes the largest cases series ( $\geq 2$ cases) describing Y-stentassisted coil embolization [4, 5, 14-16, 24-39].

In the present series, 1 patient died (patient 11) as a complication of basilar artery thrombosis after deployment of a WEB device and not associated with Y-stenting. Moreover, in a second patient, in whom the WEB device protruded into the basilar artery bifurcation, Y-stenting was used effectively as a bailout maneuver (patient 30). Only 1 patient (3.3\%) had permanent neurological damage related to Y-stenting due to thrombosis of the posterior cerebral artery. One patient experienced transient aphasia after the procedure due to a small embolic infarct in the temporal lobe. We experienced 1 IST during deployment of the first stent in a tortuous A1/A2 segment, which resolved with intravenous infusion of a GPI. These complications underline the importance of adequate anticoagulation during the procedure and proper quantification of individual antiplatelet responses. Not all the participating centers in this cases series have an established protocol to quantify the response to ASA and clopidogrel. We strongly encourage platelet function assays to identify poor responders. We experienced $13 \%(4 / 30)$ thromboembolic complications. Other series with Y-stenting have reported complication rates between 11 and 31.6\% [25, 26, 29]. Most of these complications are related to thromboembolic events. Ko et al. [35] described a $25 \%$ rate of acute IST in a series in which most patients $(15 / 20)$ were treated with Y-stenting after failure of other neck remodeling techniques (balloon remodeling or single stenting). This underlines the importance of proper antiaggregation before Y-stenting. Ko et al. [35] and other authors [5, 10, 13, $15-17,25,40]$ have reported a complete resolution of procedure-related thromboembolic events after IA infusion of GPIs. The use of low-profile stents in vessels $\leq 2 \mathrm{~mm}$ may prompt the use of intravenous GPI infusions as part of the operative protocol to avoid thromboembolic complications.

Spiotta et al. [29] reported 19 cases of Y-stenting with Neuroform stents (first and second generation). The authors chose open-cell stents due to concerns about poor stent expansion with closed-cell stents at the crossing point of the Y configuration. Fargen et al. [26] reported their experience in treating 45 patients with Enterprise and Neuroform stents in a Y configuration. No significant difference was noted in procedural complications or follow-up angiographic occlusions with different stent combinations (Neuroform and Enterprise). Based on our results, braided stents like the LVIS Jr stent appear to have good conformability and expansion in a Y configuration (Fig. 4).

Behme et al. [5] treated 34 aneurysms with the LVIS Jr stent; 2 patients developed IST after stent deployment, which resolved with intravenous GPIs. This series included 11 Y-stentings. Machi et al. [13] argued that the intersection between a low-profile stent like the LEO Baby (braided) and an open-cell stent (Neuroform) theoretically reduces the risk of obstruction of the second stent at the point of intersection with the first stent. Our study includes the largest series of low-profile stents used in Y-stenting. Compared to other openand closed-cell stent series, we did not encounter an increased risk of thromboembolic events or thrombosis at the intersecting point of the stents. 
The main limitations of this study are its retrospective design, the heterogeneity of protocols at the different institutions, the lack of an independent core laboratory for imaging review, and the short duration of follow-up. However, the main aim of the paper was to describe the technical experience with the low-profile braided LVIS Jr stent in Y-stenting. The inclusion of data from multiple centers reflects real-world experience in using LVIS Jr stents for the treatment of complex wide-neck aneurysms.

\section{Conclusions}

Y-stent-assisted coiling of wide-neck bifurcation aneurysms with the LVIS Jr device is technically feasible and has a relatively low rate of complications. Moreover, follow-up imaging demonstrated very low recanalization rates.

\section{Acknowledgements}

We thank Teresa Ruggle for graphic design and preparation of the illustrations.

\section{Statement of Ethics}

This research has been approved by local IRBs.

\section{Disclosure Statement}

E.A.S.: consultant for MicroVention; T.N.N.: consultant for Penumbra; G.D.: consultant/speaker for Medtronic, MicroVention, Cerenovus, and Penumbra; shareholder of Surpass, Medina, InNeuroCo, and Three Rivers; I.L.: consultant/proctor for Medtronic, Stryker, and Codman; shareholder of Surpass, InNeuroCo, and Three Rivers; A.E.H.: consultant/speaker for MicroVention, Medtronic, Penumbra, Stryker, and GE Healthcare; A.D.: consultant for Medtronic and MicroVention; A.A.M., V.K., E.K., D.L., A.M., S.D., W.R.G., D.H., and S.O.-G.: nothing to disclose.

\section{References}

1 Chow MM, Woo HH, Masaryk TJ, Rasmussen PA: A novel endovascular treatment of a wide-necked basilar apex aneurysm by using a Y-configuration, double-stent technique. AJNR Am J Neuroradiol 2004;25:509-512.

2 Spiotta AM, Lena J, Chaudry MI, Turner RD, Turk AS: Y-stenting for bifurcation aneurysm coil embolization: what is the risk? Stroke Res Treat 2014;2014:762389.

3 Kono K, Terada T: Hemodynamics of 8 different configurations of stenting for bifurcation aneurysms. AJNR Am J Neuroradiol 2013;34:1980-1986.

4 Chalouhi N, Jabbour P, Gonzalez LF, Dumont AS, Rosenwasser R, Starke RM, et al: Safety and efficacy of endovascular treatment of basilar tip aneurysms by coiling with and without stent assistance: a review of 235 cases. Neurosurgery 2012;71:785-794.

5 Behme D, Weber A, Kowoll A, Berlis A, Burke TH, Weber W: Low-Profile Visualized Intraluminal Support device (LVIS Jr) as a novel tool in the treatment of wide-necked intracranial aneurysms: initial experience in 32 cases. J Neurointerv Surg 2015; 7:281-285.

6 Melber K, Meila D, Draheim P, Grieb D, Greling B, Schlunz-Hendann M, et al: Vascular angular remodeling by kissing-Y stenting in wide necked intracranial bifurcation aneurysms. J Neurointerv Surg 2017;9:1233-1237.

7 Wanke I, Forsting M: Stents for intracranial wide-necked aneurysms: more than mechanical protection. Neuroradiology 2008;50:991-998.

8 Cekirge HS, Yavuz K, Geyik S, Saatci I: A novel "Y" stent flow diversion technique for the endovascular treatment of bifurcation aneurysms without endosaccular coiling. AJNR Am J Neuroradiol 2011;32:1262-1268.

9 Gupta M, Cheung VJ, Abraham P, Wali AR, Santiago-Dieppa DR, Gabel BC, et al: Low-Profile Visualized Intraluminal Support Junior device for the treatment of intracranial aneurysms. Cureus 2017;9:e1037. 
10 Samaniego EA, Abdo G, Hanel RA, Lima A, Ortega-Gutierrez S, Dabus G: Endovascular treatment of PICA aneurysms with a Low-Profile Visualized Intraluminal Support (LVIS Jr) device. J Neurointerv Surg 2016;8:10301033.

11 Babiker MH, Gonzalez LF, Ryan J, Albuquerque F, Collins D, Elvikis A, et al: Influence of stent configuration on cerebral aneurysm fluid dynamics. J Biomech 2012;45:440-447.

12 Cantón G, Levy DI, Lasheras JC: Hemodynamic changes due to stent placement in bifurcating intracranial aneurysms. J Neurosurg 2005;103:146-155.

13 Machi P, Costalat V, Lobotesis K, Ruiz C, Cheikh YB, Eker O, et al: LEO Baby stent use following balloon-assisted coiling: single- and dual-stent technique - immediate and midterm results of 29 consecutive patients. AJNR Am J Neuroradiol 2015;36:2096-2103.

14 Akmangit I, Aydin K, Sencer S, Topcuoglu OM, Topcuoglu ED, Daglioglu E, et al: Dual stenting using low-profile LEO Baby stents for the endovascular management of challenging intracranial aneurysms. AJNR Am J Neuroradiol 2015;36:323-329.

15 Tureli D, Sabet S, Senol S, Andac N, Donmez H, Geyik S, et al: Stent-assisted coil embolization of challenging intracranial aneurysms: initial and mid-term results with low-profile ACCLINO devices. Acta Neurochir (Wien) 2016;158:1545-1553.

16 Kabbasch C, Liebig T, Faymonville A, Dorn F, Mpotsaris A: Initial clinical experience with a new self-expanding nitinol microstent for the treatment of wide-neck intracranial cerebral aneurysms: the Acandis Acclino stent. J Vasc Interv Neurol 2015;8:1-6.

17 Brassel F, Melber K, Schlunz-Hendann M, Meila D: Kissing-Y stenting for endovascular treatment of complex wide necked bifurcation aneurysms using Acandis Acclino stents: results and literature review. J Neurointerv Surg 2016;8:386-395.

18 Ciccio G, Smajda S, Robert T, Blanc R, Redjem H, Takezawa H, et al: Abstract WP89: preliminary single-center experience with Neuroform Atlas stent-assisted coiling for unruptured intracranial aneurysms. Stroke 2017; 48(suppl 1):AWP89-AWP.

19 Cho YD, Sohn CH, Kang HS, Kim JE, Cho WS, Hwang G, et al: Coil embolization of intracranial saccular aneurysms using the Low-Profile Visualized Intraluminal Support (LVIS) device. Neuroradiology 2014;56:543551.

20 Alghamdi F, Mine B, Morais R, Scillia P, Lubicz B: Stent-assisted coiling of intracranial aneurysms located on small vessels: midterm results with the LVIS Junior stent in 40 patients with 43 aneurysms. Neuroradiology 2016;58:665-671.

21 Grossberg JA, Hanel RA, Dabus G, Keigher K, Haussen DC, Sauvageau E, et al: Treatment of wide-necked aneurysms with the Low-Profile Visualized Intraluminal Support (LVIS Jr) device: a multicenter experience. J Neurointerv Surg 2017;9:1098-1102.

22 Feng Z, Li Q, Zhao R, Zhang P, Chen L, Xu Y, et al: Endovascular treatment of middle cerebral artery aneurysm with the LVIS Junior stent. J Stroke Cerebrovasc Dis 2015;24:1357-1362.

23 Poncyljusz W, Biliński P, Safranow K, Baron J, Zbroszczyk M, Jaworski M, et al: The LVIS/LVIS Jr stents in the treatment of wide-neck intracranial aneurysms: multicentre registry. J Neurointerv Surg 2015;7:524-529.

24 Conrad MD, Brasiliense LB, Richie AN, Hanel RA: Y stenting assisted coiling using a new low profile visible intraluminal support device for wide necked basilar tip aneurysms: a technical report. J Neurointerv Surg 2014;6:296-300.

25 Möhlenbruch M, Herweh C, Behrens L, Jestaedt L, Amiri H, Ringleb PA, et al: The LVIS Jr microstent to assist coil embolization of wide-neck intracranial aneurysms: clinical study to assess safety and efficacy. Neuroradiology 2014;56:389-395.

26 Fargen KM, Mocco J, Neal D, Dewan MC, Reavey-Cantwell J, Woo HH, et al: A multicenter study of stent-assisted coiling of cerebral aneurysms with a Y configuration. Neurosurgery 2013;73:466-472.

27 Limbucci N, Renieri L, Nappini S, Consoli A, Rosi A, Mangiafico S: Y-stent assisted coiling of bifurcation aneurysms with Enterprise stent: long-term follow-up. J Neurointerv Surg 2016;8:158-162.

28 Martínez-Galdámez M, Saura P, Saura J, Martínez A, De Campos JM, Pérez A: Y-stent-assisted coil embolization of anterior circulation aneurysms using two Solitaire AB devices: a single center experience. Interv Neuroradiol 2012;18:158-163.

29 Spiotta AM, Gupta R, Fiorella D, Gonugunta V, Lobo B, Rasmussen PA, et al: Mid-term results of endovascular coiling of wide-necked aneurysms using double stents in a Y configuration. Neurosurgery 2011;69:421-429.

30 Yavuz K, Geyik S, Cekirge S, Saatci I: Double stent-assisted coil embolization treatment for bifurcation aneurysms: immediate treatment results and long-term angiographic outcome. AJNR Am J Neuroradiol 2013;34: 1778-1784.

31 Zhao KJ, Yang PF, Huang QH, Li Q, Zhao WY, Liu JM, et al: Y-configuration stent placement (crossing and kissing) for endovascular treatment of wide-neck cerebral aneurysms located at 4 different bifurcation sites. AJNR Am J Neuroradiol 2012;33:1310-1316.

32 Akgul E, Aksungur E, Balli T, Onan B, Yilmaz DM, Bicakci S, et al: Y-stent-assisted coil embolization of wideneck intracranial aneurysms. A single center experience. Interv Neuroradiol 2011;17:36-48.

33 Castaño C, Terceño M, Remollo S, García-Sort MR, Domínguez C: Endovascular treatment of wide-neck intracranial bifurcation aneurysms with "Y"-configuration, double Neuroform ${ }^{\circledR}$ stents-assisted coiling technique: experience in a single center. Interv Neuroradiol 2017;23:362-370. 
34 Darkhabani ZM, Lazzaro MA, Zaidat 00: Pericallosal artery aneurysm treatment using Y-configuration stentassisted coil embolization: a report of four cases. J Neurointerv Surg 2012;4:459-462.

35 Ko JK, Han IH, Cho WH, Choi BK, Cha SH, Choi CH, et al: Crossing Y-stent technique with dual open-cell stents for coiling of wide-necked bifurcation aneurysms. Clin Neurol Neurosurg 2015;132:54-60.

36 Lozen A, Manjila S, Rhiew R, Fessler R: Y-stent-assisted coil embolization for the management of unruptured cerebral aneurysms: report of six cases. Acta Neurochir (Wien) 2009;151:1663-1672.

37 Muda AS, Ralib AR, Yaacob Y, Zakaria R, Bakar AA: Y-stent-assisted coil embolisation of wide-necked aneurysms using a new fully retrievable and detachable intracranial stent: report of two cases. Malays J Med Sci 2011;18:91-97.

38 Perez-Arjona E, Fessler RD: Basilar artery to bilateral posterior cerebral artery "Y stenting" for endovascular reconstruction of wide-necked basilar apex aneurysms: report of three cases. Neurol Res 2004;26:276-281.

39 Thorell WE, Chow MM, Woo HH, Masaryk TJ, Rasmussen PA: Y-configured dual intracranial stent-assisted coil embolization for the treatment of wide-necked basilar tip aneurysms. Neurosurgery 2005;56:1035-1040; discussion 1035-1040.

40 Brassel F, Grieb D, Meila D, Schlunz-Hendann M, Greling B, Melber K: Endovascular treatment of complex intracranial aneurysms using Acandis Acclino stents. J Neurointerv Surg 2017;9:854-859. 